\title{
Progressive forms and meanings: the curious case of Capeverdean
}

\author{
Fernanda Pratas \\ Centro de Linguística da Universidade de Lisboa (Portugal) \\ fcpratas@gmail.com
}

Recibido o 07/04/2018

Aceptado o 23/07/2018

\section{Formas e interpretacións do progresivo: o caso curioso do caboverdiano}

\begin{abstract}
The progressive may be described as a periphrastic construction (auxiliary + non-finite verb; for instance, in English: $B E+V$-ing) which denotes an ongoing situation at a given time, be it an instant or an interval. This general picture, however, has faced two descriptive challenges: (i) those same forms may also appear associated with other temporal readings; (ii) the progressive meaning may also be obtained through other grammatical forms. The current paper approaches these apparent mismatches from the perspective of two varieties of Capeverdean, whose arrangements between forms and meanings of the progressive may provide a crucial insight to this cross-linguistic puzzle. The description and discussion of novel data support the two steps in a brand-new proposal for this Portuguese-based Creole: (a) the superficially different morphemes that mark the progressive have a unique diachronic path, involving the preverbal marker ta and a complete progressive cycle; (b) if we frame the temporal meaning of the progressive somewhat differently, considering the existence, under specific pragmatic conditions, of a precursory stage, at least one of the mentioned mismatches will be resolved. An additional contribution of the current discussion concerns the expression of time reference in natural language, namely that past, present or future meanings do not necessarily depend on dedicated tense morphemes.
\end{abstract}

\section{Keywords}

Capeverdean; functional morphology; variation; progressive; time reference

\section{Contents}

1. Introduction. 1.1. On linguistic variation in Cabo Verde. 1.2. Methodology. 1.3. One note about diachrony. 1.4. Organization of this paper. 2. The basics. 2.1. The progressive as opposed to the perfect. 2.2. The relevant morphemes in both varieties. 3. Progressive morphology and progressive readings. 3.1. Progressive morphology with a typical progressive reading. 3.1.1. The Santiago variety. 3.1.2. The São Vicente variety. 3.2. Apparent mismatches between forms and meaning. 3.3. Puzzling case from São Vicente. 4. A unified proposal for Capeverdean progressives. 4.1. Temporal readings in both varieties: all mood and aspect. 4.2 . The diachronic path of $t a$ : a result of the progressive cycle. 4.3. They are progressives after all. 5. Conclusion and open questions.

\section{Resumo}

O progresivo pode ser descrito como unha forma perifrástica (auxiliar + verbo non finito; por exemplo en inglés: $B E+V$-ing) que denota unha situación en desenvolvemento nun tempo determinado, sexa este un instante ou un intervalo. Esta idea xeral, con todo, enfróntase con dous desafíos descritivos: (i) esas mesmas formas poden xurdir asociadas a outras lecturas temporais; (ii) a interpretación progresivo pode tamén obterse a través doutras formas gramaticais. O presente artigo aborda estes aparentes desencontros partindo da perspectiva de dúas variedades do caboverdiano, cuxas combinacións entre formas e significados do progresivo poden achegar unha contribución crucial para a resolución deste crebacabezas lingüístico. A descrición e a discusión de novos datos apoian os dous pasos que constitúen, para esta lingua crioula de base lexical portuguesa, unha proposta completamente nova: (a) os morfemas superficialmente diferentes que marcan o progresivo resultan dun único percorrido diacrónico, implicando o marcador preverbal ta e un ciclo do progresivo completo; (b) se encadramos a lectura temporal do progresivo de forma lixeiramente diferente, considerando a existencia, en condicións pragmáticas específicas, dun estadio precursor, polo menos un dos desencontros arriba referidos queda resolto. Unha contribución adicional da presente discusión relaciónase coa expresión da referencia temporal nas linguas naturais, máis concretamente co feito de as lecturas de pasado, presente e futuro non dependeren necesariamente de morfemas que comporten eses valores específicos.

Palabras chave Caboverdiano; morfoloxía de tempo; variación; progresivo; referencia temporal

Sumario

1. Introdución. 1.1. Sobre variación lingüística en Cabo Verde. 1.2. Metodoloxía. 1.3. Unha nota sobre diacronía. 1.4. Organización deste artigo. 2. O básico. 2.1. O progresivo como oposto ao perfecto. 2.2. Os morfemas relevantes nas dúas variedades. 3. Morfoloxía e interpretacións do progresivo. 3.1. Morfoloxía de progresivo cunha lectura de progresivo. 3.1.1. A variedade de Santiago. 3.1.2. A variedade de São Vicente. 3.2. Aparentes desencontros entre forma e interpretación. 3.3. Un caso intrigante de São Vicente. 4. Unha proposta unificada para os progresivos do caboverdiano. 4.1. Lecturas temporais nas dúas variedades: só modo e aspecto. 4.2. O percorrido diacrónico de ta: un resultado do ciclo do progresivo. 4.3. Ao final son todos progresivos. 5. Conclusión e cuestións abertas. 
"I wonder if you have ever thought about this? Here we are - right now. This very minute. Now. But while we're talking right now, this minute is passing. And it will never come again. Never in all the world. When it is gone, it is gone. No power on earth could bring it back again." Frankie (also known to herself as F. Jasmine), in The Member of the Wedding, a novel by Carson McCullers (1946).

\section{INTRODUCTION}

The way we express the passage of time in natural language is one of the most exciting topics in linguistics. The study partly sketched in this paper is grounded on the working definition of time as "an overall structure of events that has an arrow or directionality due to later states of the universe being produced from the earlier states"1 , and the specific linguistic phenomenon under examination is the form and meaning of the progressive in Capeverdean, a Portuguese-based Creole.

A description of the progressive in a given language must account for two levels of analysis: (i) the grammatical form that typically occurs in progressive environments (denoting an event that is ongoing at a given time, with readings that may be focalized or durative, in the words of Bertinetto $2000^{2}$ ); (ii) two types of less typical relations: (a) when this progressive form denotes other, apparently non-progressive, meanings; (b) when different morphological markings also convey a progressive interpretation. In English, for instance, the periphrastic form $B E+V$-ing is typically associated with the progressive, as in 'I was reading a book when you arrived' (focalized) or'I was reading a book while you were making dinner' (durative). But it may also be used in some future interpretations, as in 'I'm leaving'. At least in Spanish, on the other hand, the past progressive may also be expressed by the imperfecto, as in Íbamos a la playa cuando nos encontramos con Miguel'We were going to the beach when we ran into Miguel' (Cipria / Roberts 2000: 300)3.

In Capeverdean, there are some interesting mismatches of this sort that, as many linguistic phenomena in the language, have never been formally studied. In (1) we have sentences from the variety spoken in Santiago to illustrate this: (1a) presents a progressive grammatical form with what I call here a typical progressive reading - there is an ongoing dynamic situation at a given time; in (1b) we have a progressive grammatical form with a possible temporal reading (future) that, at least apparently, is not part of a typical progressive meaning; and (1c) shows a progressive reading for an embedded clause with the morphological form also used in habituals ${ }^{4}$.

$\begin{array}{lllll}\text { (1) a. } & \mathrm{N} & \text { sata } & \text { skrebe } & \text { karta } \\ & \text { 1SG } & \text { PROG } & \text { write } & \text { letter } \\ & \text { 'I am writing a letter.' } & \end{array}$

\footnotetext{
${ }^{1}$ http://www.iep.utm.edu/time/

${ }^{2} \mathrm{~A}$ focalized interpretation occurs when the event is presented as ongoing at a particular instant, either the Time of Utterance or another instant defined by the context, as in 'John was sleeping when I arrived'. A durative interpretation occurs when "the event is presented as ongoing during a stretch of time of definite duration" (Bertinetto 2000: 7). This durative interpretation often involves durational modifiers of the type 'for X time' or 'all day/morning/etc.', or temporal clauses like 'while X', in sentences similar to 'John was reading for two hours/all afternoon/while I watched the movie'.

${ }^{3}$ One reviewer correctly points out that a similar use of the imperfeito may also be found in European Portuguese: $O$ João almoçava quando tocou o telephone'João was having his lunch when the phone rang'.

${ }^{4}$ Note that I do not illustrate here the combination of a habitual morpheme with a progressive reading in a root clause because such phenomenon is still to be found in the data that I have gathered so far. There are examples of this in Swolkien (2014: 196, for the São Vicente variety) for the allomorph te, but in fact there are doubts about the real morpheme at stake there (see her note 16, on the same page). Hence, this possibility still needs to be carefully checked. For the current purposes it is sufficient to have some other, confirmed examples of what seems now a general imperfective morpheme in a progressive reading, in this case in an embedded clause.

${ }^{5}$ List of abbreviations: 1sG/1PL: first person singular/plural, etc.; COMP: complementizer; PART: participle; PROG: progressive; BA: postverbal morpheme in Santiago; TA: preverbal morpheme with a mood function associated with all time references in Santiago; TA/TE: preverbal morpheme with a modal function associated with some constructions with a non-past time reference in São Vicente; TAVA/TÁ: preverbal morpheme with a modal function associated with past time reference in São Vicente.
} 
b.

$\begin{array}{lll}\text { Sata } & \text { txobi } & \text { oxi. } \\ \text { PROG } & \text { rain } & \text { today }\end{array}$

'It is raining today.' [also meaning now]. Or 'It is raining [later] today.'

$\begin{array}{lllll}\text { c. N } & \text { odja } & \text { Maria } & \text { ta } & \text { badja. } \\ \text { 1sG } & \text { see } & \text { Maria } & \text { TA } & \text { dance } \\ \text { 'I saw Maria dancing.' } & & \end{array}$

This paper aims to provide a description of this and other Capeverdean phenomena involving the progressive, including novel data from the varieties spoken in Santiago and São Vicente. These facts observed in the language will then be discussed under a generative approach, by means of theoretical tools provided in the relevant literature on tense, aspect and mood, and focusing, for now, on the morphological forms and their relations with the temporal meaning of each sentence. The detailed syntactic analysis of these constructions, as well as a theoretical proposal regarding syntactic variation in the language, will be left for future works, given its complexity and the need to study more linguistic contexts, a wider list of grammatical properties (features regarding Case, for instance) and the sociolinguistic distribution of the different forms.

The remaining subsections in this introduction present some relevant grounds for this line of research.

\subsection{On linguistic variation in Cabo Verde}

The archipelago of Cabo Verde, off the west coast of Senegal, was a Portuguese colony until 1975. Portuguese is still, in practice, the only official language in the country, the Republic of Cabo Verde, but Capeverdean is the mother tongue of its half a million inhabitants and of virtually all the estimated one million Cape Verdeans in the diaspora. The substrate (African) languages of this Portuguese-based Creole are mainly from the Mande and Atlantic families, spoken by the slaves from the Guinea Rivers that were taken to Santiago Island in the 15th century (Carreira 1982).

Santiago, together with its neighbouring islands in the southern part of the archipelago (Maio, Brava and Fogo), is associated with the "Sotavento varieties" of the language. The capital city of Santiago is Praia, also the capital of the country. The northern group of islands (São Vicente, Santo Antão, São Nicolau, Boavista and Sal) is associated with the "Barlavento varieties". São Vicente, whose capital is Mindelo, was one of the last to be populated - only in the beginning of 19th century have the first communities been settled there (see Swolkien 2014 and references therein). Despite this, the intense commercial activities of its large harbour converted the island into the most central of its group, and it is now the second in population in the whole country, after Santiago. Therefore, even though its own language variety is the youngest, having received influences from several others and from the contact with foreign languages such as English, as well as modern European and Brazilian Portuguese, it is often the one instantly considered when the Barlavento varieties are referred to.

Capeverdean, in any of its varieties, is still not constrained by any rules of standardization nor by the formal instruction, at school, of the particularities of its grammar. It exhibits a wide range of variation phenomena, and possibly of continuous diachronic change, most of which have never been extensively described. This variation is frequently acknowledged in a general way (some speakers from São Vicente, for instance, occasionally observe that they "do not understand a word" when they listen to the Santiago variety), and there are popular examples of lexical differences, and of diverse "ways of pronouncing" some words. That lack of intelligibility between varieties, however, has never been verified under controlled circumstances. As for the variation in some structures, there are some studies that, although focused on one of the varieties, use some data from the others to compare specific morphological features (e.g. Silva 1985, 1990, Suzuki 1994, Veiga 1995, Baptista 2002, Swolkien 2014, among others). Nevertheless, as was just referred, most singularities of this linguistic variation are still undocumented, let alone analysed under a formal approach. 


\subsection{Methodology}

Many of the sentences for the comparative discussion assumed in this paper have never been published before, and in this case there is, obviously, no previous reference to include here. Their gathering in Cabo Verde, during semi-informal interviews and in elicitation sessions, is of my entire responsibility.

Others have been previously published, by other scholars or by myself, and this is locally identified. Among the latter, some have been gathered and transcribed, under my supervision, by Helderyse Rendall, in the period 2011-2013.

The current paper does not have a sociolinguistic approach and, as such, there has been here no specific concern with the statistic representation of the community. This is rather an exploratory study of the progressive in the two varieties of the language based on previous descriptions and on recent informal work with Capeverdean consultants, for which the following steps have taken place:

i. an apparent instance of a progressive construction was detected when dealing with Capeverdean sentences, either by reading some earlier descriptions of the language or by listening to more recent semi-informal interviews with Capeverdean speakers, in which they narrate some experience of their past or tell the details about some place or story they know (note that these semi-informal interviews will be part of a large corpus of oral data, but this is still under construction; this means that no specific corpus linguistics procedures have been involved so far);

ii. in all possible cases, this meaning was later confirmed, preferably with the same speakers that produced the sentence before, using an elicitation phase where a context is given so that the target sentence, if produced again, clearly points to a progressive reading; this is where some of the tools pointed out in Matthewson (2004) have been quite useful - the author even goes to the point of defending that information about meaning cannot be gathered from spontaneous discourse alone, elicitation being an indispensable tool; I am still not so sure about this radical view, but in a future paper about fieldwork in Cabo Verde, these different steps and techniques to gather information will be described in detail;

iii. when this confirmation was not possible (in the case of data gathered by other researchers, or in the case where this construction has become a point of interest only when the speaker is no longer available), the conversation context is defined, so that the intended meaning becomes clearer.

As for the orthography, I basically follow the ALUPEC (Alfabeto Unificado para a Escrita do Cabo-verdiano, approved in 1998 and officially published in 2009, which is about to change to the simpler form, still in Portuguese, Alfabeto Cabo-verdiano), with the subsequent modifications from the local six-day discussion by a group of guest specialists in December 2008. Adaptations have been made in some words to both respect the phonology of the variety in question and attempt a degree of uniformization in the written language for the current purposes. This has, therefore, been an option for this study only, and different editions may occur in future transcripts, after other factors have been considered.

\subsection{One note about diachrony}

In Portuguese, the European lexifier of this Atlantic creole language, there are two typical periphrastic forms for the progressive, associated with different dialectal varieties: ESTAR $+a+$ infinitive, and ESTAR + gerund. In the 15th century, when the Santiago Island was first populated, both forms existed, but the latter, with the gerund, was dominant. Only much later would the prevalence of the former in the northern and centre-coastal areas of Portugal, and its connection with the standard language, be a feature of European Portuguese. In the meantime, the periphrasis with the gerund has been preserved in Brazilian Portuguese, where it is the com- 
mon form to express the progressive, and also in some southern European Portuguese dialects (Martins 2016: 21).

This note is important since the Capeverdean morphological forms of the progressive might seem derived from the Portuguese ESTAR $+a+$ infinitive. Although this is the non-dominant expression in the relevant period, it might be the case that the Portuguese people who had a part in the genesis of this Creole used this less common form. But this still needs to be confirmed through a detailed sociohistorical description and, therefore, any details about the transition from Portuguese to the progressive forms in the language (discussion in section 4) concern the association with the Portuguese ESTAR, in particular its reduced form for the present tense, third person singular - tá; it does not involve the non-finite form that followed (gerund or $a+$ infinitive).

\subsection{Organization of the paper}

This paper is organized as follows. Section 2 summarizes the grounds for the new data and discussion, including a list of the relevant morphemes in both varieties and the current adaptation of a previous proposal for the expression of time reference in Santiago. Section 3 organizes a list of relevant data regarding progressive morphology and progressive readings. In section 4, we have the detailed discussion of a brand-new unified proposal for Capeverdean progressives, which also includes a more complete approach to the construction of temporal meaning in the language. Finally, section 5 lists the main conclusions of this study and also some questions that remain open, which will guide some future developments.

\section{THE BASICS}

This section includes the preliminary details behind the main discussion in this paper. In 2.1, we have a summary regarding the previous analysis of temporal interpretation in the Santiago variety that is the anchor of the current advances and proposals. In 2.2, the temporal morphemes at stake for both varieties are presented.

\subsection{The progressive as opposed to the perfect}

Previous descriptions of data from the variety of Santiago point to the fact that the salient opposition regarding grammatical aspect in that variety is between the progressive and the perfect, rather than between the imperfective and the perfective. This was proposed in Pratas (2010, $2012 \mathrm{a}, 2014)$ and is also assumed here, with some relevant adaptations. In most cases, these progressive and perfect values are not obtained through a structure that includes an auxiliary verb, such as happens in English ( $B E+V$-ing for the progressive, HAVE+participle for the perfect) and many other languages - "perfects and progressives are overwhelmingly periphrastic" (Dahl / Velupillai 2005: 2); see also Bertinetto et al. (2000) for an overview of the progressive in European languages. What we have here is rather a progressive bound morpheme, which is in complementary distribution with a zero-morpheme conveying a perfect interpretation ${ }^{6}$.

The progressive and the perfect are here seen as semantically complex categories which involve certain temporal characteristics (Smith 1991). Moreover, the following notions from the literature (Reichenbach 1947, Demirdache / Uribe-Etxebarria 2000, Klein 1994, among others) are considered in this analysis. Three different Times are relevant to the construction of tempo-

\footnotetext{
${ }^{6}$ An anonymous reviewer asks whether these really "are perfect constructions or simply past terminative ones, like the European Portuguese Pretérito Perfeito". My point is precisely that we have two different features - a past time and a perfective aspect (or, more specifically, a terminative feature with atelic predicates and a completive feature with telic predicates; see Pratas 2010) - that are captured by the null perfect analysis. We cannot say that the bare verb forms are inherently marked for past, or for perfective (or terminative), since if it were the case, we would have to postulate that the addition of the overt morpheme sata somehow cancelled both this aspect meaning and the past interpretation (the reading obtained is present progressive, and it needs the postverbal - $b a$ to convey past progressive). The null perfect morpheme, on the other hand, accounts for: (i) all these distinctions, since it is in complementary distribution with the progressive, and (ii) the past perfect readings, which occur when we have both $\varnothing$ and postverbal $-b a$.
} 
ral reference. These were labelled in Reichenbach (1947) as: (i) Speech Time (S); (ii) Event Time (E); and (iii) Reference Time (R). The proposal in Klein (1994) presents a new distinction, the one between past perfective and past imperfective, and, in his model, the relevant three times are: (i) Time of Utterance (TU), (ii) Situation Time (T-Sit), and (iii) Topic Time (TT) (see also Stowell 2014 for a discussion of this terminology). The ordering of TU regarding TT (this mediating time is defined by Klein as the time span about which an assertion is made) corresponds to (a) a past, (b) a present or (c) a future time reference, and the ordering of T-Sit regarding TT is one of (a) subsequence, (b) inclusion/coincidence or (c) precedence ${ }^{7}$. It is this inclusion or coincidence relation that corresponds to the past imperfective/perfective distinction: TU is after TT in both (thus we have a past time reference), but in the former TT is within T-Sit, whereas in the latter TT is at T-Sit. Although the terminology adopted here is the one in Klein (1994 and subsequent work), that distinction is not decisive for the current purposes, since, as said above, and as will become evident in the following sections, the salient opposition in Capeverdean is between the progressive and the perfect rather than between the imperfective and the perfective. Therefore, the three relations between T-Sit and TT mentioned above correspond, respectively, to (a) a prospective aspect, (b) the progressive or (c) the perfect.

The perfect reading at stake in this analysis considers two different states resulting from the past situation which still hold at TT:

i. one of these states may be called, in a sense, resultant state, which is "an abstract state of the event's 'having occurred"' (Portner 2011: 1230); to put this more precisely, we may say that we have a "post-time of the situation described by the predicate", as in Klein (2014: 962); in Capeverdean, this is what we get with all dynamic predicates and with some types of statives (including all instances of kridita 'believe' or gosta 'like'); note that, according to the predicate in question, the resultant state / post-time of the situations described by the predicates has different implications regarding the current state of affairs, which does not interfere with the temporal reading of the situation: T-Sit is prior to TT, which coincides with TU; moreover, for reasons related to their inherent stativity, predicates like kridita na Dios 'believe in God' are compatible with this perfect reading in their bare forms, they denote a situation prior to TT -, but are not compatible with the progressive, which is in compliance with a cross-linguistic restriction about true statives; in the same vein, and quite naturally, the morphology that has a habitual value with dynamic predicates assures, with these statives, a general imperfective value;

ii. a result state, which is part of the situation structure (Moens / Steedman 1988; Smith 1991); this is what we get with some other statives, like sta duenti 'be sick' (stage-level), e altu 'be tall' (individual-level), some instances of modals like pode 'can' or debe 'must',

\footnotetext{
${ }^{7}$ Klein later raises important questions about the notion of Time of Utterance (e.g. the speech event itself takes time; so, what slice of it are we considering here?) and suggests that "it should be replaced by the more general notion of CLAUSE-EXTERNAL TEMPORAL STRUCTURE, to which situations described by a sentence can be linked" (Klein 2009: 10). Given the current proposal on the construction of temporal reference in Capeverdean, and the intended contribution to a deeper understanding of temporal reference construction in natural language, these questions soon need to be addressed in future works. The present paper still uses, however, a simple definition for Time of Utterance, without any further complications about its duration or internal structure: it means 'now' and is the deictic temporal anchor of root clauses.

${ }^{8}$ The modal pode (at least) shows distinct requirements regarding temporal morphology according to its meaning (I thank Dominika Swolkien, p.c., for calling my attention to this in the variety of São Vicente; in fact, it is true for both varieties; see Brüser / Santos 2012 for sentences from Santiago): in the 'have permission' meaning, its bare form means present; in the 'capacity/ability' meaning, the present requires preverbal $t a$. This distinction is also active in the past: in the 'have permission' meaning, in Santiago we have podeba, in São Vicente we have pudia, a suppletive form from the Portuguese past imperfective podia; in the 'capacity/ability' meaning we have the morphemes associated with past habituals in each variety, ta podeba in Santiago and tava pode in São Vicente. Two extra notes are needed here: (i) it is common in São Vicente to have suppletive forms for stative verbs in past interpretations; in Santiago, by contrast, the morpheme -ba is operative with both stative and dynamic predicates, although there are some suppletive forms for past statives too; with some states like sabe 'know', the association V-ba is indirectly related to the past perfect, in the same vein that the bare form is associated with the present perfect: its temporal reading is anchored on the result state of a prior event that is part of its internal structure; the imperfective value that we also get is, naturally, inherent to the state, and has nothing to do with -ba; (ii) this distinction is important for the cross-linguistic treatment of the various meanings of pode 'can', with the 'have permission' meaning being more clearly a stative and the 'capacity/ability' meaning behaving more like a dynamic predicate.
} 
and some instances of sabe 'know's. In this case, we have the intuition about a past resultative event of the type 'get sick,' 'get tall', 'get permission,' 'get to know', the temporal reading being directly anchored on the current result state (TT coincides with TU and is within the T-Sit); the impossible combination of these predicates with the progressive nicely follows from this description of the situation interpreted as a result state (as said above, states are not compatible with the progressive).

Regarding the variety spoken in the inland of Santiago Island, we obtain the following temporal orderings for all dynamic predicates in root clauses, as mentioned above:

Aspect:

a. the bare verb form means that T-Sit precedes TT - we get a perfect reading;

b. a progressive morpheme means that T-Sit includes/coincides with TT.

Time reference:

c. when something in the context (linguistic or not) orders TU after TT, which is generally visible through the suffix $-b a$, we have past perfect and past progressive readings, respectively;

d. in the absence of that information, the coincidence between TU and TT is assumed through a pragmatic inference, thus corresponding to a present perfect and a present progressive $^{10}$.

This is more evident in Table 1.

\begin{tabular}{|l|c|c|c|}
\hline & temporal ordering & temporal ordering & temporal reference \\
\hline $\begin{array}{l}\text { bare verb (null per- } \\
\text { fect morpheme) }\end{array}$ & T-Sit precedes TT & TU and TT coincide & Present Perfect \\
\cline { 2 - 4 } $\begin{array}{l}\text { progressive mor- } \\
\text { phology }\end{array}$ & $\begin{array}{c}\text { T-Sit includes /coincides } \\
\text { with TT }\end{array}$ & TU is after TT & Past Perfect \\
\cline { 2 - 4 } & & TU is after TT & Past progressive \\
\hline
\end{tabular}

Table 1. Temporal relations established by the perfect and the progressive

Two additional notes are convenient at this point. One is that, unlike the English perfect, the perfect readings in Capeverdean described in (a) are not incompatible with adverbials like 'yesterday'. The other is that, as said above, in (i) (on page 108), the few statives included in the description in (a) are incompatible with the progressive strictly for semantic reasons that have been described cross-linguistically for many statives, which is slightly different from the one described above for the derived states in (ii) (on pages 108-109).

In the next section, I will describe several progressive contexts in the language.

\subsection{The relevant temporal morphemes in both varieties}

This section has the only function of listing and illustrating the temporal morphemes in both varieties under study, spoken in Santiago and in São Vicente.

- Santiago morphemes
a. preverbal ta
b. preverbal sata
- used in past and non-past habituals, attitudinals, generics, futures
- used in progressive constructions

\footnotetext{
${ }_{9}^{9}$ Depending on other elements in the sentence, the meaning of sabe may correspond to 'know' (state) or 'get to know' (dynamic situation). The proposal here is that, in the case of the former meaning, we have a complex situation structure which includes a past event, 'got to know', plus its result state, where the temporal reading is anchored.

${ }^{10}$ Note that this is different from saying that present time reference is an absolute tense and all others are relative tenses ('relative' and 'absolute' here used as defined in Comrie 1985, Smith 2007, among others).
} 
c. zero/null (ø)

d. postverbal $-b a$
- gives the bare form of some predicates what seems a past reading

- combines with the above morphemes in different readings

Some of these readings for the variety spoken in Santiago are illustrated in the examples below, adapted from Pratas (2014: 839-840).

(2) $\operatorname{taV}$

[present attitudinal / habitual / future]

$\mathrm{N}$ ta kume pexe (tudu dia) / (na djanta).

1SG TA eat fish (every day) / (PREP dinner)

'I am a fish eater. /'I eat fish (every day).' /'I will eat fisher at dinner.'

(3) sata V

$\begin{array}{llll}\text { [present progressive] } & \\ \mathrm{N} & \text { sata } & \text { kume } & \text { pexe. } \\ \text { 1SG } & \text { PROG } & \text { eat } & \text { fish }\end{array}$

'I am eating (the) fish.'

(4) $\varnothing \mathrm{V}$

[present perfect]

$\mathrm{N}$ kume pexe na djanta.

1SG $\varnothing$ eat fish PREP dinner

'I have eaten (the) fish at dinner.'

(5) $\varnothing \mathrm{V}-b a$

[past perfect]

$\mathrm{N}$ kumeba pexe na djanta antis di N ba deta.

1SG $\varnothing$ eat:BA fish PREP dinner before of $1 \mathrm{sg}$ go lie.down

'I had eaten fish at dinner before I went to bed.'

(6) ta V-ba

a. [past: attitudinal / habitual]

$\begin{array}{lllll}\text { N ta } & \text { kumeba pexe } & \text { (tudu dia). } \\ \text { 15G } & \text { TA } \quad \text { eat:BA fish } & \text { (every } & \text { day) } \\ \text { 'In the old days, I was a fish eater.' / } & & \\ \text { 'In the old days, I used to eat fish (every day).' }\end{array}$

b. [conditional / future of past]

(Si N podeba)/(Dia siginti), $\quad \mathrm{N}$ ta kumeba pexe na djanta.

(if 1sG can:BA) / (day following,) 1sG TA eat:BA fish PREP dinner

'(If I could,) / (The next day,) I would eat fish at dinner.'

(7) sata V-ba

[past progressive]

$\begin{array}{llllll}\text { Kelora N } & \text { ka } & \text { bai } & \text { pamodi N } & \text { sata } & \text { kumeba. } \\ \text { that time 1SG } & \text { NEG } & \text { go } & \text { because 1SG } & \text { PROG } & \text { eat:BA }\end{array}$

'At that time I haven't left because I was eating.'

'At that time I haven't left because I was eating.' 
- São Vicente morphemes (adapted from Swolkien 2014)
a. preverbal ta or te
- used in non-past habituals, attitudinals,
b. preverbal tita or tite generics, futures
c. $\quad$ zero/null $(\varnothing)$
- used in non-past progressive constructions
- gives the bare form of some predicates what
d. preverbal tava or tá seems a past reading
- used in habituals in the past, and also in others with different readings
e. $\quad$ preverbal tava or tá
combined with ta or te - used in progressives in the past

Note: as is pointed out in Swolkien (2014), there is a phonological distinction between ta [te] and tá [ta] - the latter is here signalled with an accent.

Some of these readings are illustrated in the examples below, adapted from Swolkien (2014).

(8) ta / te V

(Swolkien 2014: 193)

$\begin{array}{lllllll}\text { a. No } & \text { ta } & \text { falá } & \text { más } & \text { e } & \text { kriol. } & \text { [present habitual] } \\ & 1 \mathrm{PL} & \text { TA } & \text { speak more } & \text { FOC } & \text { Creole } & \end{array}$ 'What we speak more is Creole.'
b. Pex te nadá na ága. [present generic] fish TE Swim PREP water

'Fish swim in water.'

(9) tita / tite V

(Swolkien 2014: 173)

Txuva tita dá

[present progressive]

rain PROG give

'It is raining.'

(10) $\varnothing \mathrm{V}$

Txuvê $\quad$ mut.
rain $\varnothing \quad$ a.lot
'It has rained a lot.'

(Swolkien 2014: 173)

mut.

[present perfect]

'It has rained a lot.'

(11) tava / tá V

Es tava ba bská kmida [...]. [past habitual/ conditional]

3PL TAVA go bring food

'They used to go and bring food.' / 'They would go and bring food.'

(12) tava/tá + ta/te V (Swolkien 2014: 205)

$\begin{array}{lllll}\text { PAIGC } & \text { tava } & \text { te } & \text { governá pais [...]. } & \text { [past progressive] } \\ \text { PAIGC TAVA } & \text { TE } & \text { rule country } & \end{array}$

'[at that time] PAIGC was ruling the country.'

In São Vicente, a past perfect sentence with a value correspondent to what we have in (5), for Santiago, is built with a suppletive form of the Portuguese 'had', tinha, plus a past participle, as in (13):

(13) tinha + past participle ～(Swolkien 2014: 169)

Já-I tinha bind di San Tomé [...].
already-3sG had come from San Tomé
'He had already come back from San Tomé [...].'


There are a few periphrastic forms expressing various temporal values which involve some auxiliaries, sometimes modified by the above bound morphemes. In the urban areas of Santiago, this is the case with the progressive form sta $+t a+\mathrm{V}$. We know that sta is an auxiliary because, besides behaving as a copula in other contexts (which is a common feature among auxiliaries), in progressive contexts in the past it also hosts the affix - ba. This variant of the progressive will be included in the following sections. In São Vicente, there is also a periphrastic form for the progressive, but it is confined to the mood/aspect combinations that we will see in subsection 4.2 .

\section{Progressive morphology and progressive readings}

As was mentioned earlier, typical progressive markers and progressive readings do not always coincide. On the one hand, progressive markers may appear in sentences with other temporal meanings. In English, for instance, a construction of the type $B E+\mathrm{V}$-ing is admitted in future interpretations, as in 'I'm leaving (tomorrow)'11. On the other hand, progressive readings may arise from other morphological combinations. This is the case in Spanish, where we may have an imperfecto construction with a past progressive meaning, as in Íbamos a la playa cuando nos encontramos con Miguel 'We were going to the beach when we ran into Miguel' (Cipria / Roberts 2000: 300). Some types of apparent mismatches are also attested in Capeverdean, and this section presents examples of these from both linguistic varieties under analysis here. Before that, in 3.1, we have sentences with progressive morphology and typical progressive interpretations, in the present and in the past ${ }^{12}$. Then, in 3.2, we have sentences with progressive morphology and possibly an apparent non-progressive reading, and also progressive readings in the absence of progressive morphology; finally, in 3.3, a puzzling case from São Vicente is added, although it will be left for future analysis.

\subsection{Progressive morphology with a typical progressive reading}

This subsection describes sentences from the Capeverdean varieties of Santiago and São Vicente where a coincidence exists between the morphological markings for progressive and typical progressive readings, as was briefly illustrated in (1a). Note that, for Santiago, we have two distinct ways of marking the progressive morphologically ${ }^{13}$.

In some cases, a context of the sentence is provided, so that we may have less doubts, if any, about the meaning of what is being said.

\subsubsection{The Santiago variety}

In Santiago there are two equivalent strategies to mark the progressive morphologically in root clauses - a progressive morpheme and a periphrastic construction. There are variants/allomorphs of the progressive morpheme in some inland villages of the island, as is briefly mentioned in subsection 4.2, but they are not illustrated in this paper.

\footnotetext{
${ }^{11}$ I refer the reader to Kranich (2010) for a detailed discussion of Comrie (1976, 1985), Dahl (1985, 2000), and Ljung (1980), among many others, on the English $B E+$ V-ing construction in general, and more specifically on how it "is used in a greater variety of contexts than is typical of a progressive marker" (Kranich 2010: 33). The reader may also want to see Portner (2011) for an overview of various analyses of the English perfect and progressive, and also Ramchand (2018).

${ }^{12}$ Note that only a focalized interpretation, where the event is presented as ongoing at a particular instant, is represented in all these examples. The durative interpretation, which, as said earlier, occurs when "the event is presented as ongoing during a stretch of time of definite duration" (Bertinetto 2000: 7), still needs to be carefully tested. This will be crucial to help define, in future works, the different relations of inclusion / coincidence between the Topic Time and the Situation Time.

${ }^{13}$ Note again that, in São Vicente, there is also a periphrastic version for the progressive, but it is only required in very specific contexts, which are illustrated in subsection 4.2.
} 
- Progressive morpheme in a present sentence.

Context: a mother asks her child, with an expression of disapproval:

(14) Miriam, bu sata kume bolu antis didjanta? Miriam, 2sG PROG eat cake before of dinner 'Miriam, are you eating cake before dinner?'

- Progressive morpheme in a past sentence.
(15) Kantu bu when 2sG txiga $\mathrm{N}$ sata kumeba banana. 'When you arrived, I was eating a banana.' eat:BA banana

- Periphrastic construction in a present sentence.

Context: Rui is waiting for Djon, and, since he does not know why Djon is taking so long, he asks Maria, who replies:

$\begin{array}{llllll}\text { Djon } & \text { sta } & \text { ta } & \text { nxina } & \text { Maria badja funana } \\ \text { Djon } & \text { AUX } & \text { TA } & \text { teach } & \text { Maria dance funana }\end{array}$

'Djon is teaching Maria [how to] dance funana.'

- Periphrastic construction in a past sentence.

\begin{tabular}{|c|c|c|c|c|c|c|c|}
\hline $\begin{array}{l}\mathrm{N} \\
1 \mathrm{SG}\end{array}$ & $\begin{array}{l}\text { purgunta, } \\
\text { ask }\end{array}$ & $\begin{array}{l}\text { pamodi } \\
\text { because }\end{array}$ & $\begin{array}{l}\text { e } \\
3 s G\end{array}$ & $\begin{array}{l}\text { staba } \\
\text { AUX:BA }\end{array}$ & $\begin{array}{l}\text { ta } \\
\mathrm{TA}\end{array}$ & $\begin{array}{l}\text { dura } \\
\text { take.long }\end{array}$ & $\begin{array}{l}\text { ku } \\
\text { with }\end{array}$ \\
\hline
\end{tabular}
'I asked, because he was taking a long time to come.'

\subsubsection{The São Vicente variety}

In this variety there is one typical strategy for marking the progressive - preverbal morphemes for present or past environments. Note that both progressive morphemes in this variety may have different shapes (see 2.2), but these allomorphs seem to occur in the same syntactic contexts and have the same readings.

- Progressive morpheme tite (present reading). (Pratas 2012b)

Context: a young man is telling an episode from his childhood; he once arrived home too late because he had been watching a soccer game on tv at the local café, and his father was waiting for him, very angry.

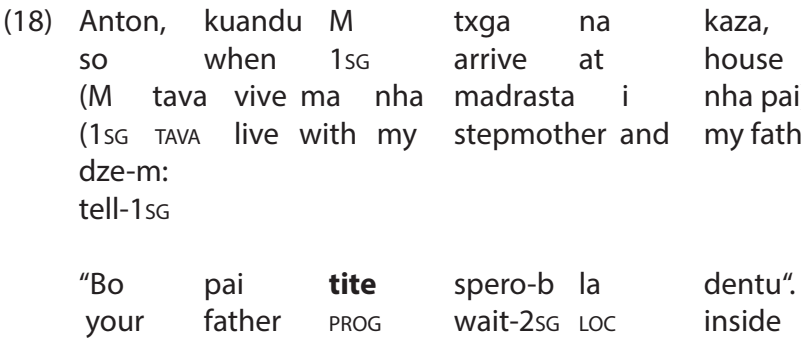

'So, when I arrived home, my stepmother (I lived with my stepmother and my father)... my stepmother told me: 'Your father is waiting for you inside.'

- Progressive morpheme tita (present reading). (Pratas 2012b)

Context: a basic school teacher speaks about some of the challenges in her profession; in this case, she focus on the current relationship between parents and children, as opposed to when the mothers used to stay at home. 
(19) Grinhasin, pai ta sai, mai ta sai, anton es tita now father TA go.out mother TA go.out, so 3PL PROG dxa kargu di edukasau de ses fidjus so pa skola. leave charge of education of their children only for school 'Nowadays, the father goes out, the mother goes out, and so they are leaving all the education of their children to school.'

- Progressive morphemes tava ta (past reading).

(20) Onte di noti, kuandu Joao txga, Ana ainda tava ta trabalha. yesterday of night when Joao arrive Ana still PROG work 'Yesterday evening, when Joao arrived, Ana was still working.'

- Progressive morphemes tá te (past reading). (Pratas 2012b)

$\begin{array}{llllll}\text { (21) Kuandu } & \mathrm{M} & \text { termina } & \text { nha formasau, N } & \text { pasa } \\ \text { when } & 1 \mathrm{SG} & \text { finish } & \text { my } & \text { training, 1SG } & \text { spend } \\ \text { un } & \text { anu } & \text { sen } & \text { trabalhu } & & \\ \text { one } & \text { year } & \text { without } & \text { work } & & \\ \text { purke nu } & \text { tá te } & \text { spera desizau di } & \text { ministeriu di edukasau. } \\ \text { because } & 1 \mathrm{PL} & \text { PROG } & \text { wait decision of } & \text { ministry of education }\end{array}$
'When I finished my training, I didn't work for a year because we [me and my colleagues] were waiting for the decision from the ministry of education.'

\subsection{Apparent mismatches between forms and meanings}

In this subsection I present contexts and sentences, also for both varieties, where we may have an apparent mismatch between the morphological markings and the temporal readings - in each case, only one of them (morphology or reading) is typically progressive. In these examples, the relevant morphemes do not have glosses, for their true meaning will be discussed in section 4 .

i. Progressives with some type of future reading, as was briefly illustrated in (1b). Note that, for São Vicente, we have ba 'go' in these sentences, as in the English construction 'I'm going to'. In other words, the full temporal interpretation seems dependent on this verb of motion (which is cross-linguistically involved in future readings - Bybee et al. 1994: 267-268). These examples were nevertheless included here because this notion conveyed by ba 'go' will be at stake in my proposal for all of them; as can be seen right now, the English translations for all these already include 'BE going to'.

- Santiago (Pratas 2007: 42)

(22) Sata txobe oxi.
SATA

'It's raining today.' but also 'It is going to rain today.'

- Santiago (Pratas 2007: 90)

(23) Parse-m ma seems-1sG COMP Suzana SATA marry:BA

'It seems to me that [at that time] Suzana was going to get married.'

- São Vicente (with 'go') (Swolkien 2014: 195)
(24) $M$

tita
ba muda
di káza.
1SG TITA go change
of house
'I am going to move to a new house.' 
- São Vicente (with 'go') (Pratas 2012b)

(25) Nton, kel dia Benfica tava te bafaze ultimu jogu di kampeonatu. so that day Benfica TAVA TE go make last game of championship 'So, on that day Benfica was going to make the last game of the championship.'

ii. Progressive readings with what seems non-progressive morphology, as was briefly illustrated in (1c).

- Santiago (Pratas 2007: 74)

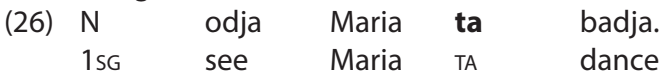

'I have seen Maria dancing.'

- São Vicente

$\begin{array}{llllllll}\text { (27) M uvi nha } & \text { vzinha ta kanta durante duaz } & \text { ora. } \\ \text { 1sG hear my } & \text { neighbour TA sing } & \text { during two } & \text { hour } \\ & \text { 'I have listened to my neighbour singing for two hours.' }\end{array}$

\subsection{Puzzling case from São Vicente}

In the São Vicente variety, which, as has been said, is younger than the one spoken in Santiago, there is an intriguing marker that brings about some further questions: tive or teve, which look like reduced forms of the Pretérito Perfeito of estar, the Portuguese auxiliary 'be' (stage-level), for singular first and third persons, estive and esteve, and then followed by te (possibly a variant of ta). To my knowledge, it has never been documented; it was brought to my attention by a Portuguese speaker living in Mindelo ${ }^{14}$. Let me now illustrate this.

Context: the bilingual child (she speaks Portuguese and Capeverdean, São Vicente variety) wants to tell her father that she has already seen this movie which is now showing on tv; she says:

Dja-M tive te oiá es filme.
Dja-1SG TIVE TE watch this movie
Literally: 'I already was seeing this movie.'
Intended meaning:'I already saw this movie.' [a while ago]

My consultants say that they do not know exactly what this tive te means, but the intuition of the person who brought this to my attention is that it is used with situations that took place in a somewhat distant past. The sentence above shows it in the context of a durative situation, as 'see the movie'. My future line of inquiry regarding this will consider that the Portuguese forms estive/esteve or tive/teve (oral reduced forms) may be used as a copula, as in Eu estive /tive em casa toda a manhã'I was home all morning', or as an auxiliary in a progressive, as in Eu estive / tive a ler toda a manhã'l was reading all morning ${ }^{\prime 15}$. Note that, in this same variety of São Vicente,

\footnotetext{
${ }^{14}$ Swolkien registers the homophonous form tive, from the Portuguese simple past of ter 'have', but not the 'tive' that is at stake here.

${ }^{15}$ In a prior version of this paper, I called this a 'perfective progressive' (see Arche 2014, 2018), and one anonymous reviewer observed that "it is not perfectivity (in its aspectual sense) but terminativity that is involved in these [Portuguese] cases". It is true that, according to Smith (1991: 107), when we combine an activity with a perfective viewpoint, we present a terminated event: at some arbitrary point, the activity is terminated. But this is not the case here, for nothing is said about the termination of the reading activity (which might have continued through the afternoon - we may have a continuation, like in São 3 h da tarde! Eu estive a ler toda a manhã e ainda estou! Literally: 'It's 3pm! I was reading all morning and still am!'). Hence, and as I have defended before (Pratas 2012: $81 \mathrm{ft} .16$, and 2014: 850), what we have here is the closure of an interval defined by the durative adverbial toda a manhã 'all morning', which must be treated as an argument of the situation itself then, since it has ended, what is closed/bounded is the situation modified by it, not the one expressed by the progressive predicate alone. I believe that constructions of this type correspond to the durative reading of the progressive pointed out in Bertinetto (2000).
} 
the past perfect reading of the type proposed for bare dynamic verbs is obtained with another suppletive form from Portuguese, tinha 'had' ${ }^{\prime 16}$; in Santiago the verbal affix - $b a$ is used in theses contexts. This contrast is visible in (29):

(29) a. [...] algen tinha jdod el fi. [São Vicente] (Swolkien 2014: 216) someone had help:PART 3sg run.away '[...] someone had helped him run away.'

b. Numeba pexe na djanta. [Santiago] (Pratas 2014: 849)
1SG eat:BA fish PREP dinner
'I had eaten fish at dinner [...]'

The sentences in (28) and (29a), from São Vicente, include suppletive forms of Portuguese auxiliaries (they are past forms of estar 'be' and ter 'have', respectively). This shows that there is here no productive independent marking for tense.

In the next section, I provide a proposal for the typical progressive sentences in both Capeverdean varieties, and for the apparent mismatches described in 3.2. I will adopt an event-based analysis of the progressive that may account for some apparent non-progressive readings of progressive morphology (we shall see that their meaning is part of a progressive reading after all). As for some progressive readings of apparently non-typical progressive morphology, the solution looks straightforward for the Capeverdean case, through a novel account for the diachrony of $t a$. A comparative approach to other languages where the imperfective occurs in sentences with a progressive meaning will be left for future studies, trying to figure out whether a diachronic analysis along these lines also applies, or rather a more semantic-centered perspective gives better results - considering, for instance, that the relevant context narrows the meaning of the general imperfective to a more specific progressive interpretation.

\section{A unified proposal for Capeverdean progressives}

Analyses of the progressive have been divided into the modal approach (Dowty 1977, 1979, Landman 1992, and Portner 1998, among many others), which defines the progressive as an operator that modifies the event and involves quantification over possible worlds, and the event-structure approach (ter Meulen 1985, Bach 1986, Parsons 1990, and Szabó 2008, among many others). The current proposal assumes the latter, in the sense that the progressive is here viewed as denoting a part of a situation which exists independently of what happens after TT. This means, among other things, that even with telic situations the past progressive does not impose any lexical change regarding the culmination, since it only refers to a slice of the situation prior to the culmination instant (see also Arche 2014, on a similar proposal grounded on Spanish data).

The present proposal for Capeverdean progressives consists of three steps, corresponding to the next three subsections. In 4.1 we have a complete account of the temporal readings in root clauses in both varieties - this involves the extension of the proposal in 2.1 to the variety of São Vicente and, in so doing, a brand-new approach to some of the morphemes involved. Then, in 4.2 we have a novel proposal for the embedded ta that shows a progressive reading, accounting for this through the diachronic path of this morpheme. Finally, the progressive sentences with apparent future readings will be analysed in subsection 4.3.

\footnotetext{
${ }^{16}$ This suppletive form tinha 'had' has, in the São Vicente variety, two uses that are equivalent to Portuguese, both Brazilian and European: as an auxiliary in past perfect constructions (see example in 29a), and as the past of the main verb 'have', for possession. But it also has another use that, in Portuguese, only exists in the Brazilian varieties: in past existential constructions, like ka tinha ramed 'there was no solution' (adapted from Swolkien 2014: 211).
} 


\subsection{Temporal readings in both varieties: all mood and aspect}

With the purpose of better explaining the current analysis of the progressive meaning, we must go back to the temporal readings in the language, now extending the previous proposal regarding the Santiago variety to the younger one of São Vicente.

Recall from subsection 2.1 that, regarding the variety spoken in Santiago, we obtain the following temporal orderings for root clauses. Aspect: (i) the bare verb form means that T-Sit precedes TT - we get a perfect reading; (ii) a progressive morpheme means that T-Sit includes/ coincides with TT. Time reference: (i) when something in the context (linguistic or not) orders TU after TT, which is made visible through the suffix - $b a$, we have a past perfect and a past progressive reading, respectively; (ii) in the absence of $-b a$, the coincidence between TT and TU is assumed through a pragmatic inference, thus corresponding to a present perfect and a present progressive.

Now we can apply this to the São Vicente variety, where there is no $-b a$, being the past and non-past environments associated with different morphemes for the progressive and the habitual, in the following way (summary from subsection 2.2): non-past progressive - tite or tita; past progressive - tava ta, tava te, tá ta, tá te; non-past habitual - ta, te; past habitual - tava, tá.

With all these facts in mind, what follows is a unified proposal for the temporal readings in the language.

A. In the absence of any linguistic or extra-linguistic information bringing about a different interpretation, the Topic Time (TT) coincides with the Time of Utterance (TU). This is coherent with: (i) the proposal of a perfect reading in root clauses with bare verbs, and (ii) the contrast between these, on the one hand, and the progressives and the habituals, on the other hand. Look at the following set of sentences: again, we have a bare form conveying a past event information (through a null perfect morpheme) in (30a), a progressive (30b) and a habitual (30c) - given the right context, this sentence may have a future reading.

(30) a

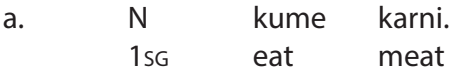

'I have eaten meat.'

b.

$\begin{array}{llll}\mathrm{N} & \text { sata } & / \\ \text { 1 SG } & \text { PROG (Santiago) } & / \\ \text { Il am eating meat.' } & & \\ \mathrm{N} & \text { ta } & \text { kume } & \text { karni. } \\ \text { 1SG } & \text { TA } & \text { eat } & \text { meat }\end{array}$

'I eat meat.'/'I will eat meat.'

tita kume karni. PROG (São Vicente) eat meat

$\begin{array}{llll}\text { c. } & \mathrm{N} & \text { ta } & \text { kume karni. }\end{array}$

Contrasts such as (30) were used elsewhere to defend that modern ta has a complex modal/ quantificational function (Pratas 2010, 2012a), and, as such, ta was not included in the temporal analysis for Santiago presented in 2.1, which was focused on other distinctions. Under a very specific perspective, however, this needs no longer be the case. Going straight to the point, my current take on modern ta uses Comrie's (1985: 45) definition of irrealis:

[...] some languages have a basic modal distinction between realis and irrealis, where realis refers to situations that have actually taken place or are actually taking place, while irrealis is used for more hypothetical situations, including situations that represent inductive generalisations, and also predictions, including also predictions about the future.

The assumption here is, thus, that Capeverdean ta is associated with the irrealis mood, occurring in future and hypothetical meanings, and also in habituals (see Suzuki 1994 for a similar proposal), which can be viewed as "inductive generalizations". Under this view, all the meanings of Santiago ta in root clauses are nicely accounted for: habituals (past and present) and future or conditionals (including counterfactuals). Thus, ta is not a tense marker, meaning non-past, as was 
proposed in Silva (1985), since it also occurs in past constructions in Santiago. This was well noted in Baptista (2002). But Baptista, on the other hand, proposes that ta also marks realis mood, and with this she means habituals (Baptista 2002: 79-80). Just to make things very clear, ta in root clauses never marks realis, in Comrie's sense. For realis in this sense - of "situations that have actually taken place or are actually taking place" ${ }^{\prime \prime}$, we have the perfect and the progressive ${ }^{17}$.

Therefore, going back to the ordering between TT and TU, which in Klein's model defines time reference, we have again the same relation of coincidence for all the root clauses in (30). The different temporal interpretations are entirely derived from other features (aspectual, for the perfect and the progressive, and modal, for the habitual): in the perfect, T-Sit precedes TT, hence the situation has occurred before TU (this is why it is interpreted as past); as for the habitual and the progressive, T-Sit includes TT, which means that it also includes TU (and thus the situation is interpreted as present). Note that there are more subtle differences between these two (progressive and habitual), which lie in the specific nature of the relation between T-Sit and TT: in the progressive, we have an ongoing dynamic situation at TT; in the habitual, what is coincident with TT is a situation presented as a kind of property/generalization, not any specific instance of eating meat (see Comrie 1985: 39). Finally, in certain contexts, the irrealis mood allows for the situation to be presented as hypothetical (with different degrees of commitment from the speaker); T-Sit is after TT and TU, which corresponds to a future interpretation.

B. Since the past versions of these constructions always need a context (linguistic or extra-linguistic) that locates TU after TT, the main function of the morphemes that are associated with past perfects, past habituals and past progressives could be said to be marking tense (and this has been assumed in Pratas 2010, 2012a, 2014 for Santiago -ba). They are, however, better analysed as a type of temporal agreement/concord markers, licensed by the time reference brought about by the context. The syntax of the functional categories involved is left for future research, as well as the syntactic relation of these morphemes with any temporal adverbs that occur in the sentence. For the current purposes, I add some notes on the distributional properties of these overt morphemes (-ba for Santiago; the more complex tava or tá for São Vicente) which can help better account for their nature as temporal agreement/concord rather than purely tense morphemes:

i. they may also occur at least in one type of constructions that do not have a past reading: some conditionals. It is true that, in these cases, they can be analysed as a 'fake tense', as they have been in Pratas (2010), following the proposal in latridou (2000) for Modern Greek. As Smith also puts is, "in certain contexts, a tense has atemporal meanings - most clearly perhaps in conditional sentences. Past tense is often associated with non-actual, irrealis, and distanced meanings" (Smith 2007: 421, ft.4). But then a question arises: what would be the point of insisting that a morpheme marks tense (which, within the current analysis, strictly refers to the relation between TT and TU) only to dismiss this contribution as 'fake tense' or 'atemporal meaning'?

ii. in Santiago, postverbal -ba may be repeated in the same root indicative clause (occurring with two verbs, the second being most probably an equivalent to a non-finite form), as in N kreba serba veterinario'I want:BA be:BA vet'. Our intuitions about the different con-

\footnotetext{
${ }^{17}$ There is an ongoing debate about the contrast between realis and irrealis and how this divide may apply cross-linguistically. For the current purposes, however, it does not seem problematic to establish a relation between, on the one hand, a set of temporal meanings that includes conditionals, counterfactuals, futures and habituals, and, on the other hand, the irrealis mood. Besides this being in line with Comrie's definitions, as said above, it is coherent with other authors' proposals in this respect. In their paper about Yurakaré, an unclassified language of central Bolivia, van Gijn / Gipper (2009) point out that, in some languages, like the one they are studying, the habitual is also part of the irrealis category. They mention "Givón's (1994: 270) observation that both habitual and irrealis are temporally non-specific", further elaborating that Givón (1994) considers "the habitual to be of hybrid modality, combining realis features (actual occurrence) with irrealis features (non-referential and temporally unspecific)" (van Gijn / Gipper 2009: 172-174). They also point out that other authors have found other correlations, mainly between irrealis and the imperfective aspect, of which the habitual is a subcategory. Given these observations and the fact that those temporal constructions involve ta in Capeverdean (always ta in Santiago; ta or tava / tá in São Vicente), a natural conclusion, for now, is that in these contexts this morpheme signals irrealis mood, not tense or aspect.
} 
tributions of these two - $b a$ 's can be captured if we say that the higher - $b a$, on the 'wish' verb, is licensed by the time reference provided by the context (this utterance is part of a narrative), and the second -ba is a temporal agreement/concord morpheme controlled by the higher - ba. As a side note: any speculations that this lower -ba might be a type of subjunctive marker are contradicted by the fact that, according to Palmer (2006; see also Matthewson 2010), subjunctive markers in Indo-European languages are not independent from person and number agreement paradigms - which do not exist in Capeverdean; therefore, a single subjunctive morpheme would be here typologically odd.

iii. in São Vicente, tava or its allomorph tá present even more difficulties regarding a strict tense marker analysis, since there is no such element independent of aspect or mood morphemes (see next subsection); moreover, these forms have a more limited distribution regarding past time contexts: they do not occur in past perfect constructions, which are in this variety of the type tinha + some form corresponding to a participle, like skrivid 'writen' or oiod'seen'; and they do not modify some statives either, which, in the context of a past time reference, always resort to other suppletive forms from Portuguese, like sabia 'knew' (Santiago: sabeba) or pudia'could' (Santiago: podeba).

For all these semantic and distributional reasons, the less specific account of these various allomorphs as temporal agreement/concord is certainly the most adequate at this point.

In Tables 2 and 3 we have, for the two varieties, the different temporal interpretations connected with the mood and the aspect morphemes in simple root clauses. While the description regarding aspect follows the previous proposal that was summarized in 2.1, the current analysis of the values for $t a$ is different from any previous explanation, in that it now accounts for all its occurrences (see next subsection).

\begin{tabular}{|c|c|c|c|}
\hline \multirow{2}{*}{} & perfect & progressive & irrealis \\
\cline { 2 - 4 } & $\begin{array}{c}\mathrm{V} \\
\text { habitual or prospective }\end{array}$ \\
\hline $\begin{array}{c}\text { TU coincides } \\
\text { with TT }\end{array}$ & $\begin{array}{c}\text { sata } \mathrm{V} \\
\text { (present perfect) }\end{array}$ & $\begin{array}{c}\text { ta } \mathrm{V} \\
\text { (present habitual or future) }\end{array}$ \\
\hline $\begin{array}{c}\text { TU is after TT } \\
\text { (provided by the } \\
\text { context) }\end{array}$ & $\begin{array}{c}\mathrm{V}-\mathrm{ba} \\
\text { (past perfect) }\end{array}$ & $\begin{array}{c}\text { sata } \mathrm{V} \text {-ba } \\
\text { (past progressive) }\end{array}$ & $\begin{array}{c}\text { ta } \mathrm{V} \text { - } b a \\
\text { (past habitual or conditional) }\end{array}$ \\
\hline
\end{tabular}

Table 2. In Santiago: mood and aspect values, also with the temporal agreement/concord -ba

\begin{tabular}{|c|c|c|c|}
\hline \multirow{2}{*}{} & perfect & progressive & habitual or prospective \\
\cline { 2 - 4 } & $\begin{array}{c}\mathrm{V} \\
\text { TU coincides } \\
\text { with TT }\end{array}$ & $\begin{array}{c}\text { tita/tite } \mathrm{V} \\
\text { (present progressive) }\end{array}$ & $\begin{array}{c}\text { ta or } \text { te } \mathrm{V} \\
\text { (present habitual or future) }\end{array}$ \\
\hline $\begin{array}{c}\text { TU is after TT } \\
\text { (provided by the } \\
\text { context) }\end{array}$ & $\begin{array}{c}\text { tinha } \mathrm{V} \\
\text { (past perfect) }\end{array}$ & $\begin{array}{c}\text { tava or tá }+ \\
\text { ta or } \text { te } \mathrm{V} \\
\text { (past progressive) }\end{array}$ & $\begin{array}{c}\text { tava } \text { or tá } \mathrm{V} \\
\text { (past habitual or conditional) }\end{array}$ \\
\hline
\end{tabular}

Table 3. In São Vicente: mood and aspect values, also with the temporal agreement/concord tavaltá

We may then conclude that the language has no specific grammatical form for marking tense, since there is an opposition that is strictly of mood (realis vs. irrealis) and, within the realis mood, there is an aspectual opposition between the perfect and the progressive. We have in fact specific morphemes associated with the past-shifted versions of these mood and aspect meanings, but they look like temporal agreement/concord morphemes rather than tense. In other 
words, we may have TU after TT, but there are various constructions where there is no exact match between this ordering - past time reference -, on the one hand, and these morphemes, on the other hand, as was pointed out in B, above.

Tables 2 and 3 only apply to simple root clauses, for other types of clauses have specificities of their own - and these more complex contexts is where the subtleties of these mood and aspect morphemes become more visible. Among these cases are the embedded verbs mentioned in $B(i i)$, which may have, in Santiago, the verbal affix - ba. Another case is the embedded clauses marked by $t a$, and this is common to both varieties. This embedded ta is the topic of the next subsection.

\subsection{The diachronic path of ta: a result of the progressive cycle}

Previous studies have acknowledged the progressive value of Capeverdean ta "in some embedded contexts which look like non-finite environments", yielding simultaneity with respect to the Topic Time - the one established in the matrix clause (Pratas 2007: 41-42). We have seen examples in (26) and (27), and the sentence in (31) illustrates this too:

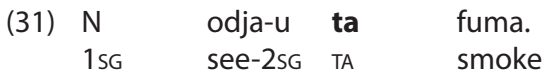

'I have seen you smoking.'

Trying to find a diachronic account for the fact that ta, mostly known as participating in habituals, also appears in these progressive clauses, Jacobs (2011) establishes a relation between this progressive use of Capeverdean ta in embedded contexts and the well-known progressive marker ta in Papiamentu. Papiamentu is also a Portuguese-based Creole in the Atlantic and is believed to have the same origin as Capeverdean and the Guinea Bissau Creole, namely a proto-Creole which emerged in Santiago in the 15th century and later migrated to the African continent and to the Caribbean. Furthermore, the author proposes that ta started "as a general imperfective marker ([+habitual, +progressive])" and that "[gradually], alternative periphrastic progressives would then come to absorb an important part of progressive aspect in [Capeverdean]" (Jacobs 2011:328). He also refers to the observation in Kihm (1994) that "in some previous stage of the language, ta covered the whole field of the imperfective" (Kihm 1994: 92).

My current proposal for the diachrony of Capeverdean ta is more radical: it started in progressive constructions and was subject to a complete progressive cycle. The progressive to general imperfective path is a well-known phenomenon at the morphological and the semantic levels (Dahl 1985, Bybee / Dahl 1989, Bybee et al. 1994, Deo 2015, among others). It roughly consists of the following steps: progressive markers emerge in languages often in the form of periphrastic expressions; they later undergo a process of grammaticalization and generalize their use to less specific imperfective contexts; new progressive markers emerge to fill the gap left by this shift of the previous marker to a general imperfective. Therefore, my take is that $t a$ started as a progressive marker, from the Portuguese reduced form of está, the third person singular of estar 'BE (stage-level)'18. This is in line with Schuchardt's (1882: 911, translated in Hagemeijer / Holm 2008) observation that, "originally", Capeverdean N ta da means, in Portuguese, eu estou dando or eu estou a dar'I am giving', a meaning that has later "blurred to eu dou"'I give' (adapted from Hagemeijer / Holm 2008: 148). Hence it underwent a process of grammaticalization, generalizing its use to a general imperfective meaning, which includes habituals. Under this view, the value of $t a$ as a general imperfective corresponds to an intermediate stage, not the beginning, as was proposed in Kihm (1994) and Jacobs (2011) - note that the grammaticalization process goes from progressive to imperfective, not the other way around. The need to keep the progressive meaning clearly marked then got this morpheme some reinforcement, adding a new word before it, typically a locative auxiliary. In Santiago, another periphrastic construction was thus obtained: sta

\footnotetext{
${ }^{18}$ As was said earlier, it is not relevant whether the following non-finite verb form was $a+$ infinitive or a gerund, according to the Portuguese variety at stake; only this reduced form of estar, tá, is important here.
} 
$t a$, with sta being a true auxiliary, as was said above - it may be marked by preverbal ta (in habituals) and affixed by - $b a$, and adverbs like so 'only' or sempri 'always' may appear between sta and the embedded $t a$, as in (32a). Moreover, as is typical of auxiliaries, in different contexts sta can be a main verb, in this case a copula, in stage-level predicate constructions (32b) (Pratas 2007: 64).

(32) a.

a. Maria ta staba
Maria TA be:BA
'Maria was always washing
b. Juau sta duenti.
Juau be sick
'Juau is sick.'

$\begin{array}{llll}\text { sempri } & \text { ta } & \text { laba } & \text { mo. } \\ \text { always } & \text { TA } & \text { wash } & \text { hand }\end{array}$

Later on, it seems that this locative auxiliary sta got, in some places, reduced to sa, and here we get the most widespread of the current non-periphrastic progressive forms in that island - note that sa does not obey any of the diagnostics for being an auxiliary illustrated in (32): it cannot be marked by other morphemes, it cannot be separated from the following $t a$, and it does not occur on its own in copular constructions (Pratas 2007: 64) ${ }^{19}$.

In what is still a pure speculative hypothesis to be explored in upcoming historical studies, it is possible that ta was at some intermediate stage of this diachronic path during its migration to São Vicente, where the first stable communities settled in the beginning of the 19th century. This might explain the different reinforcement for the progressive that developed in this variety: ti rather than sta/sa. This hypothesis gains some strength with the fact that there are other morphemes preceding ta in progressive constructions for other varieties, like in ata or aita, in other villages in the inland of Santiago. The dialectal variants of this reinforcement morpheme will, in a near future, be analysed under the approach that functional categories are the locus of linguistic variation (see the conjecture Borer-Chomsky, as formulated in Baker 2008, from Borer 1984 and Chomsky 2001; Adger / Smith 2010, Fábregas et al. 2015, among many others).

Given this diachronic path of $t a$, its progressive meaning in the embedded contexts pointed out above does not come as a surprise ${ }^{20}$. I propose that, in these embedded cases, ta has preserved, in both varieties, its progressive value, and this may be so for two reasons: (i) there is no ambiguity requiring the reinforcement of the progressive: within the scope of a perceptive verb like 'see' or 'listen', the requirement of an unfolding event is intuitive enough for the imperfective meaning of ta to be narrowed accordingly - in other words, for any habitual reading to be excluded; (ii) in these embedded contexts, the relation between T-Sit and TT is defined by the semantics of the matrix clause rather than by a locative morpheme; thus, diachronically, a word with this exclusive contribution was never inserted here ${ }^{21}$.

At this point, some notes are required about two facts that, among the two varieties under study here, are specific to São Vicente. One is that the morpheme associated with habituals in the past is tava (or tá), and another is that the combination associated with the progressive in the past is tava (or tá) + ta (or te). This could lead us to the hypothesis that this tava is a locative auxiliary inflected for past (which would be a reason to resume the discussion about true tense morphemes - the case would be that an auxiliary ta was marked for past with -va, which would have the phonological effect of lowering its vowel; then, this effect would be preserved in the reduced form, tá). This would not be coherent, however, with the distributional properties of taval tá, which behaves as a bound morpheme as much as $t i$, in the present progressive tita or tite. In fact, when we need a true periphrastic form, then stod is required. This word, which seems a lo-

\footnotetext{
${ }^{19}$ It is interesting, however, that sá is still attested as a predicative and locative copula in Casamancese Creole (http://apics online.info/surveys/34), another language that is argued to have originated from the proto-creole born in Santiago (Jacobs 2010 and references therein).

${ }^{20}$ In the same fashion, it might account for any other cases of ta still occurring in root progressive constructions, if these are safely attested in the future.

${ }^{21}$ Note that this embedded ta cannot be an instance of an irrealis mood marker, as was argued above for it in root clauses, since the situation is here understood as being "actually taking place".
} 
cal participial form of the correspondent Portuguese auxiliary - in Portuguese, this participle is estado -, has been analysed as having "an idiosyncratic form and behaviour. On [the] one hand, its form resembles participles, but on the other it behaves as a main verb" (Swolkien 2014: 250). As a copula, it appears translated as 'to be' in Swolkien (2014), but I believe that 'to turn', 'to get', 'to become' or 'to stay' are better translations, since they capture this type of eventive/resultative meaning. These copula contexts are illustrated in (33) (Pratas 2012b).

(33) a

$\begin{array}{llllll}\text { Kuandu } & \text { M } & \text { txga } & \text { na liseu..., } & \text { bo } & \text { sabe, } \\ \text { when } & \text { 1SG } & \text { arrive } & \text { at highschool, } & \text { 2sG } & \text { know, } \\ \text { bo } & \text { ta stod } & \text { mas } & \text { grandi... } & & \\ \text { 2SG } & \text { TA STOD } & \text { more } & \text { big } & & \end{array}$

'When I entered high school..., you know, you become more grown up...'

b.

$\begin{array}{llllll}\text { Un } & \text { ves, pais tá } & \text { stod na kaza, } \\ \text { one time parents TÁ } & \text { STOD in } & \text { house, } \\ \text { ta } & \text { kuida } \quad \text { di fidju... } & & & \\ \text { TA } & \text { take.care of child } & & \\ \text { 'In the old days, parents used to stay at home, taking care of their children...' }\end{array}$

As an auxiliary, stod is obligatory in some progressive constructions: when the progressive is within the scope of a modal (34a); when the progressive is within the scope of the mood morpheme ta or tá (habituals in the present, 34b, or in the past, 34c); here, the speaker may include some adverbials or quantifiers (34d) (this is equivalent to 32a, from Santiago). In these cases, the verb that is the complement of this auxiliary is, as expected, obligatorily preceded by ta or te, which is part of the progressive construction.

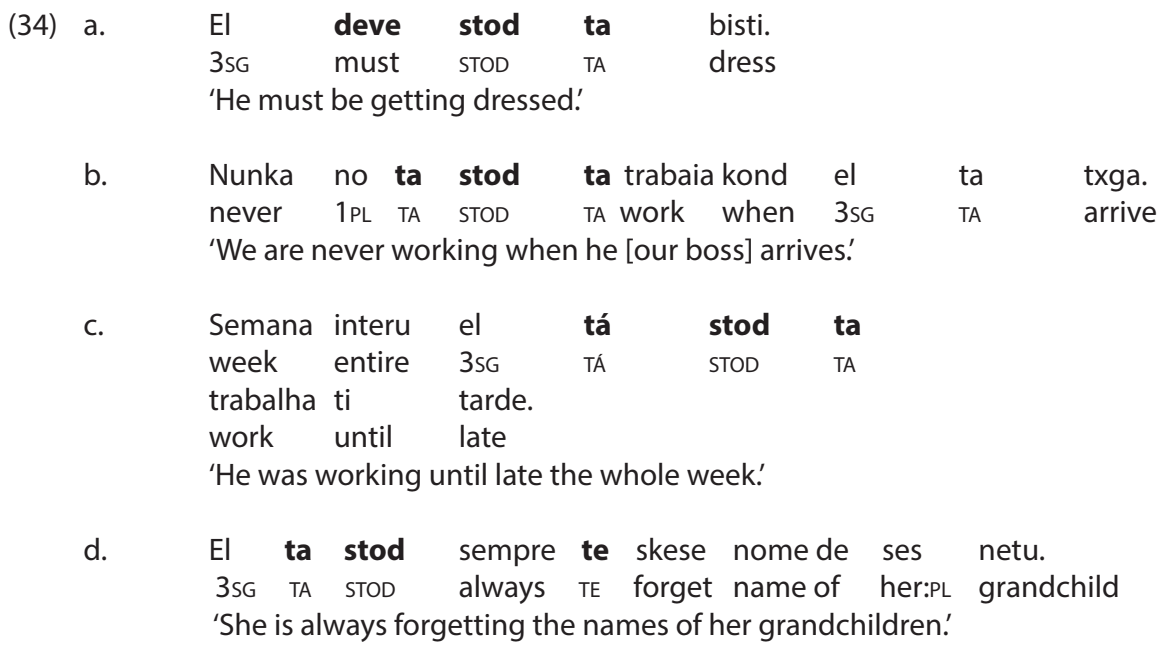

Therefore, and in conformity with the above line of inquiry, it seems straightforward to assume that, since there is no postverbal $-b a$ in this variety (for some reason which needs a dedicated investigation), somewhere along the diachronic change of ta a specific morpheme emerged to reinforce the progressive in the past ( $t i$ or te fulfil this function in the present); by analogy with the Portuguese first and third persons singular, past imperfective of estar, which is estava and has an oral reduced form tava, this Capeverdean tava developed both as a mood marker (on its own, in habituals) and as the reinforcement of progressives (thus followed by ta or te), providing agreement/concord with past environments, but appearing also in conditionals, as was pointed out in $\mathrm{B}(\mathrm{i})$, in subsection 4.1 . 
In this subsection, I have advanced a brand-new integrated analysis of preverbal ta that accounts for: (i) all the occurrences of this morpheme in both varieties - even if in Santiago its use extends to past habituals and conditionals, and in São Vicente these are reserved for tava or tá; (ii) the dialectal variation in the current progressive markers, which result from a complete progressive cycle.

\subsection{They are progressives after all}

As we have seen in 3.2, another apparent mismatch in Capeverdean regards the future reading of sentences with progressive morphology. This looks less intriguing for the cases from São Vicente with the auxiliary ba 'go', a verb of motion that is often included in future constructions cross-linguistically. But it may be quite puzzling for the simple form sata $\mathrm{V}$, in the Santiago sentences. In this subsection I begin to explore a semantic account for this that might also be helpful to similar cases in other languages, such as the English sentence 'I'm leaving (tomorrow)'.

The notion of the progressive as describing an ongoing situation at Topic Time is connected with the different intuitions about what an 'ongoing situation' really means. I will not get into the details of the so-called "imperfective paradox" (Dowty 1977), which involves the (in)completion of telic situations in past progressives - in this respect, I will only refer the reader to Smith (1997), who, among others, does not see anything paradoxical in the combination of a progressive with a telic situation, since "[one] does not have to know the outcome of a particular event to know" that it is telic (or atelic) (Smith 1997: 96). Therefore, for one type of telic and for atelic situations (accomplishments and activities, respectively), the progressive is here interpreted as referring to their stage at TT; this means that, in the case of accomplishments, there is no need to postulate anything about the culmination part. As Arche (2014) puts it, "[with] heterogeneous predicates in the progressive, a part of the event is understood as instantiated. It is not that the predicate becomes homogeneous; a part of it is understood as having occurred, as other authors have also pointed out (e.g., Verkuyl 1999)" (Arche 2014: 799-800). As for achievements, which are defined as having no activity part - they involve time instants (Vendler 1957: 149) -, I defend that the use of the progressive does not need to convert them into accomplishments; we may interpret the progressive as referring to a precursory stage that is not a part of the achievement situation itself. In this case, the Time of Situation is interpreted somewhere within the natural continuation of this precursory stage.

In this line of reasoning, I propose that we account for the future readings with progressive morphology combined with all situation types by assuming that, at TT, which in this case is coincident with TU, there is some precursory stage of the type just proposed for achievements. This precursory stage means that if I say, for instance, $N$ sata txiga oitu ora 'I'm arriving at $8 \mathrm{~h}$ ', there is something already happening that I believe will contribute for me to arrive at $8 \mathrm{~h}$ (either I am already in motion or some other committed preliminary action is taking place). This might be the same for sentences like 'I'm leaving', in English: someone who says this believes themselves to be somehow already committed with the act of leaving, even if it is only a question of having decided to do so. When we have a future marked by a verb of motion like ba 'go' in the progressive (see example (24), from São Vicente), this meaning of a precursory stage external to the structure of the situation denoted by the predicate is more visible - 'I'm going' does not necessarily mean that I am moving geographically, but that I am moving on an imaginary line representing a course of events that will lead to the situation denoted by the predicate. Just one more note about volition: this future interpretation of the progressive does not imply a subject with a specific attitude; it may be so, with some predicates, but it may also be the case that there is no subject. Observe the sentence in (22), here repeated as (35), which may have a future interpretation of the progressive with a verb that has no subject.

(35) Sata txobe oxi.

SATA rain today

'It's raining today.' but also 'It is going to rain today.' 
This is important to show that the precursory stage involved in this interpretation may be connected only with the signs that are observable by the speaker, or the information that they get from the forecast news - in any case, there is the intuition that something is already happening that will, with a great level of confidence, lead to the future situation. Table 4 shows these possible temporal readings regarding the situation denoted by the predicate with present progressive morphology (in which the Topic Time, TT, includes/coincides with the time of utterance, TU) with each event type.

\begin{tabular}{|c|c|c|c|}
\hline activity part of the situation & activities & accomplishments & achievements \\
\hline $\begin{array}{c}\text { T-Sit } \\
\text { simultaneous with TT } \\
\text { (and TU) = present }\end{array}$ & $\begin{array}{c}\text { T-Sit } \\
\text { simultaneous with TT } \\
\text { (and TU) = present }\end{array}$ & $*$ \\
\hline $\begin{array}{c}\text { precursory stage (leading to the } \\
\text { situation denoted by the predi- } \\
\text { cate, but not part of it) }\end{array}$ & $\begin{array}{c}\text { T-Sit after TT (and TU) } \\
\text { = future }\end{array}$ & $\begin{array}{c}\text { T-Sit after TT (and TU) } \\
\text { = future }\end{array}$ & $\begin{array}{c}\text { T-Sit after TT (and } \\
\text { TU) = future }\end{array}$ \\
\hline
\end{tabular}

Table 4. Location of T-Sit (Time of Situation) for different event types and present progressive morphology

As we can see here, for activities and accomplishments both an activity part and a precursory stage are available, while only the precursory stage is available for achievements, for there is no activity part within their structure. For every situation type, the availability of a future reading must obey two requirements: (i) the adequate context that allows for this marked interpretation - through time adverbials or the time reference induced by another clause (as in the sentence made famous by Culicover / Jackendoff (1997: 195), for other reasons: 'you drink one more can of beer and I'm leaving'), and (ii) the pragmatic conditions that make them possible, namely the inferences about a degree of commitment/evidence that most certainly will lead to the referred situation in a future time.

Among the open questions to be addressed in further developments of this analysis, one concerns this relation between a progressive aspect - which belongs to realis mood - and a prospective interpretation - which has been argued here to belong to irrealis mood. The solution to this will have to find more arguments in favour of the temporal interpretation (present: $\mathrm{TU}=\mathrm{TT}$ ) as being anchored on the precursory stage, which is presented as unfolding (progressive aspect), leaving the irrealis mood as a feature which is inherent to the prospective situation denoted by the predicate (T-Sit after TT).

\section{Conclusion and open questions}

Within the specific scope of the current exploratory study, a novel proposal has been advanced regarding the apparent mismatches between progressive readings and progressive morphology in two varieties of Capeverdean. This proposal has two steps:

(a) the superficially different forms that mark the progressive (one of them in root clauses and the other in some embedded causes) have a unifying diachronic path, involving the preverbal marker ta: this morpheme underwent a complete progressive cycle, which means that it started as a progressive marker, then generalized its use to habituals, and was later reinforced in progressive contexts (subsection 4.2);

(b) if we frame the temporal meaning of the progressive somewhat differently, including the possibility of its connection with a precursory stage, we account for the fact that some present progressives allow for a future interpretation of the situation denoted by the predicate (4.3).

An additional contribution of the current discussion concerns the expression of time reference in natural language, namely that the past, present or future meaning of a sentence may be attained without any dedicated tense morphemes. This occurs in Capeverdean in the following way: there is a distinction that is strictly of mood (realis vs. irrealis) and, within the realis mood, 
there is an aspectual distinction between the perfect and the progressive. We have in fact specific elements associated with the past-shifted versions of these mood and aspect meanings, but they behave like temporal agreement/concord morphemes rather than strict tense markers.

As was pointed out at different stages of this article, there are significant points left for future research. One of these concerns the syntactic structure that emerges from the current proposal on the construction of time reference in Capeverdean. Namely, what is the relation between mood and aspect? Moreover, do we need a Tense Phrase (TP) to accommodate the time reference (semantics) at stake in each sentence, even though this is obtained without any functional elements whose precise function is to mark grammatical tense (morphology)? And where do we locate the less specific temporal agreement/concord morphemes? If there is no TP, is the functional structure of the sentence headed by IP, Inflection Phrase, similarly to what is proposed in Ritter / Wiltschko (2014) for different native languages of America? The authors argue that Infl is indeed the universal category responsible for anchoring the event on the uttering situation. This needs to be investigated for this Portuguese-based Creole, through a careful analysis of a large corpus of oral data.

Still regarding the syntax of these constructions, it will be interesting to analyse the variation that we find, especially the one concerning ta V-ba in Santiago in contrast with tava/tá V in São Vicente. Among the points of micro-variation that mark these two dialects, this one is particularly fascinating, for these morphemes have some different distributional properties. Besides an extensive description of their features and restrictions, they will be analysed under the approach known as the conjecture Borer-Chomsky (Baker 2008), according to which functional categories are the locus of linguistic variation.

Other issues that are left for future investigation were not even mentioned here but are quite stimulating just the same. They fall within the scope of sociolinguistics and will be addressed in future work, following interviews and inquiries specifically planned for this purpose: (i) the true distribution of the variants described above; (ii) the existence of intra-individual variation; and (iii) any extra-linguistic factors, such as different linguistic attitudes, involved in the choices made by the speakers, for some of these options may seem closer to European Portuguese, the language of the colonizer.

\section{ACKNOWLEDGEMENTS}

This work has been sponsored by national funding through FCT, Fundação para a Ciência e a Tecnologia, IP, within the scope of LUDVIC - Language Unity and Diversity: Variation in Capeverdean and beyond (IF/00066/2015), an exploratory research project associated with my current position as Investigador FCT.

I want to thank all my consultants in Cabo Verde and Lisboa, the audience in the workshop Tenselessness (Greenwich, London, October 2017), and Dominika Swolkien and Tiago Mouta Leão, in São Vicente. Finally, I am also very grateful for the extremely positive insights and advice that I received from two anonymous reviewers whose suggestions I have applied almost entirely. The subsisting errors and inaccuracies are, as always, my own.

\section{References}

ALUPEC: Alfabeto Unificado para a Escrita do Cabo-verdiano. Decreto-Lei No. 8/2009, Boletim Oficial da República de Cabo Verde, Praia 19.03.2009, I Série No.11, 74-76.

Adger, David / Jennifer Smith (2010): "Variation in agreement: A lexical feature-based approach", Lingua 120, 1109-1134. doi: https://doi. org/10.1016/j.lingua.2008.05.007
Arche, María J. (2014): "The construction of viewpoint aspect: the imperfective revisited", Natural Language and Linguistic Theory 32, 791-831. doi: https://doi.org/10.1007/s11049-013-9209-5

Arche, María J. (2018): "A solution to the durative puzzle: a progressive syntax for parts and iteration". London: University of Greenwich, Ms. 
Bach, Emmond (1986): "The algebra of events", Linguistics and Philosophy 9(1), 5-16.

Baker, Mark (2008): "The macroparameter in a microparametric world", in Theresa Biberauer (ed.), The limits of Syntactic Variation. Amsterdam/ Philadelphia: John Benjamins, 351-374. doi: https://doi.org/10.1075/la.132.16bak

Baptista, Marlyse (2002): The Syntax of Cape Verdean Creole, the Sotavento varieties. Amsterdam/ Philadelphia: John Benjamins. doi: https://doi.org/ 10.1075/la.54

Bertinetto, Pier Marco (2000): "The progressive in Romance, as compared with English", in Östen Dahl (ed.), Tense and Aspect in the Languages of Europe. Berlin/Boston: De Gruyter, 559-603.

Bertinetto, Pier Marco / Karen H. Ebert / Casper De Groot (2000): "The progressive in Europe", in Östen Dahl (ed.), Tense and Aspect in the Languages of Europe. Berlin/Boston: De Gruyter, 517-558.

Borer, Hagit (1984): Parametric Syntax. Dordrecht: Foris.

Brüser, Martina / André dos Reis Santos, with the contribution of Ekkehard Dengler and Andreas Blum, under the direction of Jürgen Lang (2012): Dicionário do Crioulo da Ilha de Santiago (Cabo Verde) com equivalentes de tradução em alemão e português. Tübingen: Gunter Narr Verlag.

Bybee, Joan L. / Östen Dahl (1989): "The Creation of Tense and Aspect Systems in the Languages of the World", Studies in Language 13, 51-103. https://www.unm.edu/ jbybee/downloads/ BybeeDahl1989TenseAspectSystems.pdf

Bybee, Joan L./ Revere Perkins / William Pagliuca (1994): The evolution of grammar. Tense, Aspect, and Modality in the Languages of the World. Chicago: University of Chicago Press.

Carreira, António (1982): O Crioulo de Cabo Verde, Surto e Expansão. Mem Martins: Europam.

Chomsky, Noam (2001): "Derivation by phase", in Michael Kenstowicz (ed.), Ken Hale: A life in language. Cambridge: MIT Press, 1-52.

Cipria, Alicia / Craige Roberts (2000): "Spanish Imperfecto and Pretérito: truth conditions and Aktionsart effects in a situation semantics", Natural Language Semantics 8(4), 297-347.

Comrie, Bernard (1976): Aspect. An Introduction to the Study of Verbal Aspect and Related Problems. Cambridge: Cambridge University Press.
Comrie, Bernard (1985): Tense. Cambridge: Cambridge University Press.

Culicover, Peter W. / Ray Jackendoff (1997): "Semantic subordination despite syntactic coordination", Linguistic Inquiry 28(2), 195217. doi: https://doi.org/10.1093/acprof:oso/ 9780199271092.003.0013

Dahl, Östen (1985/Reprinted 1987): Tense and Aspect Systems. Oxford: Blackwell.

Dahl, Östen (ed.) (2000): Tense and Aspect in the Languages of Europe. Berlin: De Gruyter.

Dahl, Östen / Viveka Velupillai (2005): "Tense and Aspect", in Martin Haspelmath et al. (eds.), The World Atlas of Language Structures. OxALUPEC: Alfabeto Unificado para a Escrita do Cabo-verdiano. Decreto-Lei No. 8/2009, Boletim Oficial da República de Cabo Verde, Praia 19.03.2009, I Série No.11, 74-76.

Demirdache, Hamida / Myriam Uribe-Etxebarría (2000): "The primitives of temporal relations", in Roger Martin / David Michaels / Juan Uriagereka (eds.), Step by step: Essays on minimalist syntax in honor of Howard Lasnik. Cambridge: MIT Press, 157-186.

Deo, Ashwini (2015): "The semantic and pragmatic underpinnings of grammaticalization paths: the progressive to imperfective shift", Semantics \& Pragmatics 8, 1-52. doi: http://dx.doi. org/10.3765/sp.8.14

Dowty, David (1977): "Towards a Semantic Analysis of Verb Aspect and the English 'Imperfective' Progressive", Linguistics and Philosophy 1: 45-78. http://www.jstor.org/stable/25000028

Dowty, David (1979): Word Meaning and Montague Grammar. Dordrecht: Reidel.

Fábregas, Antonio / Jaume Mateu / Michael T. Putnam (2015): "'Parameters' in linguistic theory: What, where, and how", in Antonio Fábregas / Jaume Mateu / Michael T. Putnam (eds.), Contemporary Linguistic Parameters. London/New York: Bloomsbury Publishing, 3-24

van Gijn, Rik / Sonja Gipper (2009): "Irrealis in Yurakaré and other languages: On the cross-linguistic consistency of an elusive category", in Lotte Hogeweg / Helen de Hoop / Andrej L. Malchukov (eds.), Cross-linguistic Semantics of Tense, Aspect, and Modality. Amsterdam/ Philadelphia: John Benjamins, 155-178. doi: https:// doi.org/10.1075/la.148.07gij

Givón, Talmy (1994) "Irrealis and the subjunctive", Studies in Language 18(2), 265-37. doi: https:// doi.org/10.1075/sl.18.2.02giv 
Hagemeijer, Tjerk / John Holm (2008): "Schuchardt, Hugo. On the Creole Portuguese of São Tomé (West Africa). Annotated translation from the German of 'Ueber das Negerportugiesische von S. Thomé (Westafrika)' Sitzungsberichte der kaiserlichen Akademie der Wissenschaften zu Wien 101(2): 889-917 [1882]", in John Holm / Susanne Michaelis (eds.), Contact Languages: Critical Concepts in Linguistics. London/New York: Routledge, 131-156.

latridou, Sabine (2000): "The grammatical ingredients of counterfactuality", Linguistic Inquiry 31 , 231-270.

Jacobs, Bart (2010): “Upper Guinea Creole: evidence in favor of a Santiago birth", Journal of Pidgin and Creole Languages 25(2), 289-343. doi: https://doi.org/10.1075/jpcl.25.2.04jac

Jacobs, Bart (2011): "Cape Verdean ta in its role as a progressive aspect marker", Papia 21(2), 315334. http://media.leidenuniv.nl/legacy/jacobs2011-capeverdean-ta-as-progressive-marker. pdf

Kihm, Alain (1994): Kriyol Syntax: the Portuguese-based creole language of Guinea-Bissau. Amsterdam/Philadelphia: John Benjamins.

Klein, Wolfgang (1994): Time in language. London: Routledge.

Klein, Wolfgang (2009): "How time is encoded", in Wolfgang Klein / Ping Li (eds.), The expression of time. Berlin: Mouton de Gruyter, 39-82.

Klein, Wolfgang (2014): "Is aspect time-relational? Commentary on the paper by Jürgen Bohnemeyer", Natural Language \& Linguistic Theory 32(3), 955-971. doi: https://doi.org/10.1007/ s11049-014-9240-1

Kranich, Svenja (2010): The Progressive in Modern English: a Corpus-Based Study of Grammaticalization and Related Changes. Amsterdam / New York: Rodopi. doi: https://doi. org/10.1163/9789042031449

Landman, Fred (1992): "The progressive", Natural Language Semantics 1, 1-32.

Ljung, Magnus (1980): Reflections on the English Progressive. Gothenburg: Acta Universitatis Gothoburgensis.

Martins, Ana Maria (2016): "Introdução: O português numa perspetiva diacrónica e comparativa", in Ana Maria Martins / Ernestina Carrilho (eds.), Manual de Linguística Portuguesa. Berlin/Boston: De Gruyter MRL Series, 1-39.
Matthewson, Lisa (2004): "On the methodology of semantic fieldwork", International Journal of American Linguistics 70, 369-415. doi: https:// doi.org/10.1086/429207

Matthewson, Lisa (2010): "Cross-linguistic variation in modality systems: the role of mood", Semantics \& Pragmatics (3) Article 9, 1-74. doi: https:// doi.org/10.3765/sp.3.9

ter Meulen, Alice (1985): "Progressives without possible worlds.", in William Eilfort / Paul Kroeber / Karen Peterson (eds.), The Proceedings of Chicago Linguistic Society (CLS) 21(1), 408-423.

Moens, Marc, / Mark Steedman (1988): "Temporal ontology and temporal reference", Computational Linguistics 14(2), 15-28. http://www.aclweb.org/anthology/J88-2003

Palmer, Frank (2006): Mood and modality. Cambridge: Cambridge University Press. doi: https://doi.org/10.2277/0521804795

Parsons, Terence (1990): Events in the Semantics of English. Cambridge, MA: MIT Press.

Portner, Paul (1998) "The progressive in modal semantics", Language 74, 760-787.

Portner, Paul (2011): "Perfect and progressive", in Claudia Maienborn / Klaus von Heusinger / Paul Portner (eds.), Semantics: An international hand-book of natural language meaning. Berlin: Mouton de Gruyter, 1217-1261. https:// semanticsarchive.net/Archive/jlmMTEOM/Portner-perfect-progressive-HSK-draft.pdf

Pratas, Fernanda (2007): Tense Features and Argument Structure in Capeverdean Predicates. PhD Dissertation, Universidade Nova de Lisboa. http://www.clul.ulisboa.pt/files/fernanda_pratas/pratas_PhD.pdf

Pratas, Fernanda (2010): "States and temporal interpretation in Capeverdean", in Reineke Bok-Bennema / Brigitte Kampers-Manhe / Bart Hollebrandse (eds.), Romance Languages and Linguistic Theory 2008 - Selected papers from 'Going Romance' Groningen 2008. Amsterdam/Philadelphia: John Benjamins, 215-231. doi: https:// doi.org/10.1075/rllt.2.12pra

Pratas, Fernanda (2012a): "'I know the answer': a Perfect State in Capeverdean", in Irene Franco / Sara Lusini / Andrés Saab (eds.), Romance Languages and Linguistic Theory 2010 - Selected papers from 'Going Romance 24' Leiden 2010. Amsterdam/Philadelphia: John Benjamins, 65-86. doi: https://doi.org/10.1075/rllt.4.04pra 
Pratas, Fernanda (2012b): CV Words: oral data from Cape Verde (with Helderyse Rendall). http:// crwords.org/

Pratas, Fernanda (2014): "The Perfective, the Progressive and the (dis)closure of situations: comment on the paper by María J. Arche", Natural Language \& Linguistic Theory 32(3), 833-853. doi: https://doi.org/10.1007/s11049-014-9236-x

Ramchand, Gillian Catriona (2018): Situations and Syntactic Structures: Rethinking Auxiliaries and Order in English. Cambridge MA: MIT Press.

Ritter, Elizabeth / Martina Wiltschko (2014): "The composition of INFL: an exploration of tense, tenseless languages, and tenseless constructions", Natural Language and Linguistic Theory 32, 1331-1386. doi: https://doi.org/10.1007/ s1 1049-014-9248-6

Silva, Izione Santos (1985): Variation and Change in the Verbal System of Capeverdean Crioulo. Ph.D. dissertation, Georgetown University, Ann Arbor.

Silva, Izione Santos (1990): "Tense and Aspect in Capeverdean Crioulo", in John Victor Singler (ed.), Pidgin and Creole Tense-Mood-Aspect Systems. Amsterdam/Philadelphia: John Benjamins, 143-168. doi: https://doi.org/10.1075/cll.6

Smith, Carlota (1991): The Parameter of Aspect. New York: Kluwer.

Smith, Carlota (1997): The Parameter of Aspect. Dordrecht: Kluwer Academic Publishers.

Smith, Carlota (2007): "Tense and temporal interpretation", Lingua 117, 419-436.
Stowell, Tim (2014): "Capturing simultaneity: a commentary on the paper by Hamida Demirdache and Myriam Uribe-Etxebarria", Natural Language \& Linguistic Theory 32(3), 897-915. doi: https://doi.org/10.1007/s11049-014-9241-0

Suzuki, Miki (1994): "The markers in Cape Verdean CP." Unpublished manuscript, CUNY.

Swolkien, Dominika (2014): The Cape Verdean Creole of São Vicente: its genesis and structure. Ph.D. dissertation, Universidade de Coimbra. https://estudogeral.sib.uc.pt/jspui/bitstream/10316/27018/1/The\%20Cape\%20Verdean\%20Creole.pdf

Szabó, Zoltán (2008): "Things in progress", Philosophical Perspectives 22, 499-525. doi: https:// doi.org/10.1111/j.1520-8583.2008.00155.x

Veiga, Manuel (1995): O Crioulo de Cabo Verde: Introdução a Gramática. Praia: Instituto Nacional do Livro e do Disco, Instituto Nacional da Cultura.

Vendler, Zeno (1957): "Verbs and times", The Philosophical Review 66(2), 143-160. http://semantics.uchicago.edu/scalarchange/vendler57.pdf

Verkuyl, Henk J (1999): "Tense, aspect, and aspectual composition", in Mila Dimitrova-Vulchanova / Lars Hellan (eds.), Topics in south Slavic syntax and semantics. Amsterdam: John Benjamins, 125-162.

Vlach, Frank (1981): "The semantics of the progressive", in Philip Tedeschi / Annie Zaenen (eds.), Syntax and semantics 14: Tense and aspect. New York: Academic Press, 271-292. Oxford: Oxford University Press, 266-281. 